\title{
Prosthetically driven immediate implant placement at lower molar area; an anatomical study
}

\section{Purpose}

To examine the effectiveness and safety of immediate implant placement (IIP), we evaluated the risk of lingual plate perforation (LPP) and mandibular canal perforation (MCP) associated with posterior mandible anatomy using cone beam computed tomography (CBCT) images.

\section{Materials and Methods}

A morphological study of the molar sockets of 135 patients (age: 18-84 y) was done and its relationship to the mandibular canal was investigated. The risk of LPP and MCP was recorded as yes or no. Mandibular cross-sectional morphology was defined as one of three types (U-P-C) using the criteria of Chan et al.

\section{Results}

The risk of LPP was significantly higher for second molars $(p=0.0001)$, and the risk increased with age $(p=0.039)$. There was a strong relationship between the risk of LPP and cross-section type $U(p=0.0001)$. The mean root to alveolar canal (RAC) distance $(\mathrm{mm})$ of males was significantly higher than that of females. The mean RAC value was $5.02 \mathrm{~mm}$ for males and $3.49 \mathrm{~mm}$ for females. There was no statistically significant relationship between the risk of MCP and sex. There was a significant relationship between the risk of MCP and cross-section type $\mathrm{U}(p=0.0001)$. Although the MCP risk was higher in second molars, there was no statistically meaningful relation between MCP and tooth type.

\section{Conclusion}

The results suggest that IIP in the mandibular molar area carries a high risk of MCP and LPP. Based on the elevated level of risk, a delayed implant protocol should be considered.

Keywords: $C B C T$; immediate implant; mandibular canal; lingual plate perforation; mandible

\section{Introduction}

Molars, especially first molars, frequently decay, as they are the first permanent teeth to erupt. Loss of molar teeth is associated with neighbouring tooth movement, extrusion of opposing teeth and occlusal disorders $(1,2)$. Immediate implant placement (IIP), which was introduced into clinical practice in 1978 (3), is popular among patients due to the need for only a single surgical procedure and a reduced treatment time (4). In the past, the initial purpose of implant operations was to place the implant in an area of the bone that provided support to a functional prosthesis. In this concept, osseointegration was the primary goal, and prosthetic restorations did not always meet aesthetic ideals (5).

The mandible forms the lower portion of the jaw complex and supports mastication, speech and facial expressions. The alveolar processes of the mandible consist of buccal-lingual plates, inter-dental septa and inter-radic-

\author{
Sabit Demircan ${ }^{1}$
}

ORCID IDs of the authors: S.D. 0000-0001-6933-201X

'Beykent University Vocational School Dental Services, Oral Health Program, Istanbul, Turkey

Corresponding Author: Sabit Demircan

E-mail: sabitdemircan@hotmail.com

Received: 22 May 2019

Revised: 26 July 2019 Accepted: 16 September 2019

DOI: 10.26650/eor.20200059 
ular septa (6). Several anatomical studies have shown major changes in the anatomy of the posterior mandible after tooth loss, with age and sex contributing little to these changes $(7,8)$.

The mandibular molar area is a challenging site for implant placement because of the inferior alveolar canal (IAC) and concavity of the submandibular fossa. Nerve injury can lead to a partial or permanent paraesthesia, lingual plate perforation (LPP) and sublingual or submandibular hematomas, with excessive bleeding or infection (9-11). (Figure 1) These anatomical structures not only give rise to surgical complications during implant operations but also cause fracture of the lingual plate during extractions, thereby facilitating the dissemination of microorganisms and infection to other areas (6). Furthermore, in cases of fenestration in the lingual plate, displacement of endodontic materials and iatrogenic subcutaneous emphysema are possible complications (6).

Cone beam computed tomography (CBCT) is an effective instrument to evaluate bone quality and anatomy, and it a reliable, objective method of determination of bone density values $(12,13)$.

To examine the effectiveness and safety of IIP, the present study evaluated the risk of LPP and mandibular canal perforation (MCP) associated with posterior mandible anatomy using $C B C T$ images.

The null hypothesis tested in this study was that there would be no relationship between IIP and LPP and IAC perforation.

\section{Materials and Methods}

The study protocol was approved by the institutional review board of the Istanbul University Faculty of Dentistry (2016-83). In total, CBCT images obtained from 500 patients were evaluated for fully erupted mandibular permanent

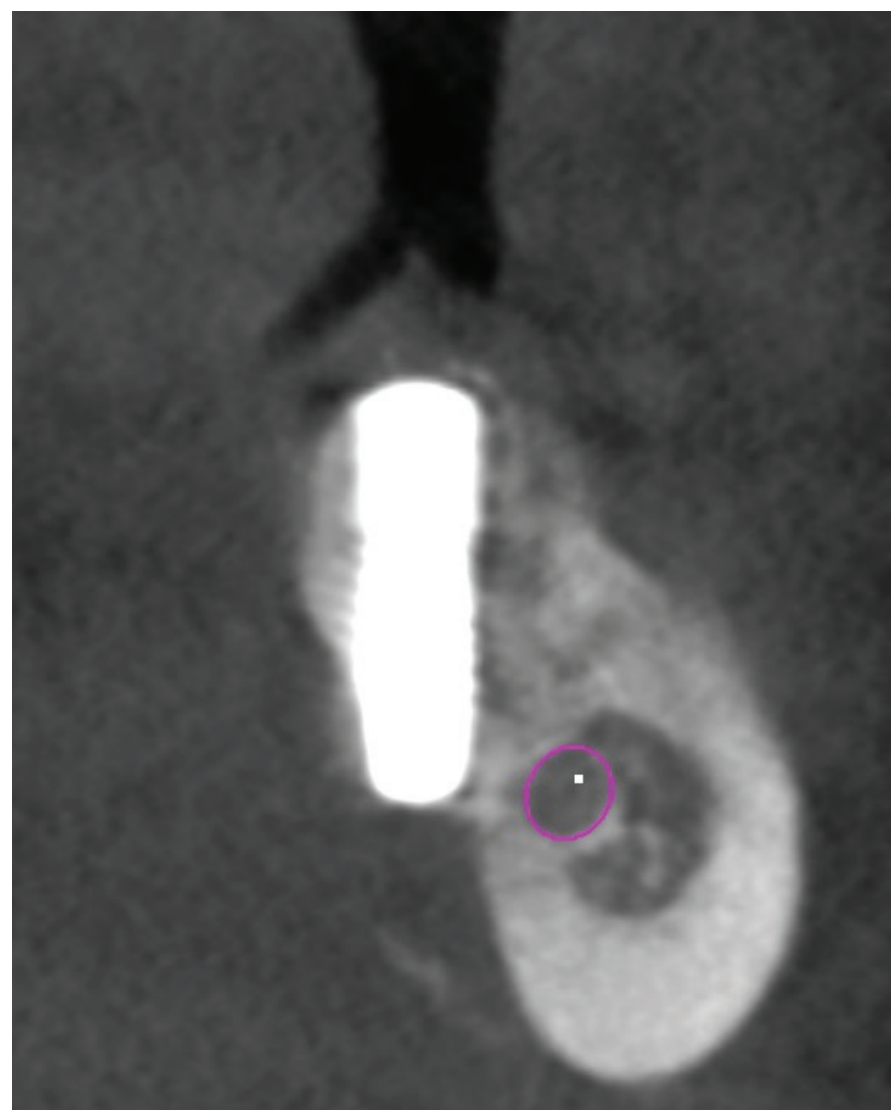

Figure 1. Lingual plate perforation. premolar and molar teeth and fully formed apexes. The exclusion criteria included uncontrolled periodontal problems, dental caries, alcohol or drug addiction, systemic/local conditions that affected bone metabolism, chemotherapy and a history of radiotherapy in the head and neck regions. Of the 500 images, 135 images met the inclusion criteria. A detailed morphological study of 292 molar sockets of these135 patients (mean age: $46.3 \mathrm{Y}$ ) was performed.

All CBCT data were obtained using the same CBCT scanner (Galileos; Sirona Dental Systems, Germany). The CBCT protocol was as follows: $98 \mathrm{kVp} / 6 \mathrm{~mA}$ and exposure time of 2-5 sec. The CBCT examinations of all patients performed for other causes and measurements were carried out using Galileos software (Sirona Dental Systems, Germany). In all the CBCT images, the field of view $12 \mathrm{~cm}$ with $1 \mathrm{~mm}$ slice thickness, as any change in the field of view could change the effective dose and affect the spatial resolution.

All the images were manipulated to provide the best resolution and magnification. In the CBCT images, the operator ensured the following:

The boundary of the mandible and IAC was clear;

Each tooth was normally positioned, and an imaginary line connecting the cusp tip of the canines and the central grooves of the premolars and molars was smooth;

The angulation of opposing maxillary teeth was correct.

Three types of mandibular cross-sectional morphologies were evaluated (U-P-C) using the criteria described by Chan et al. $(11,14)$. The $U$ type consisted of a ridge with a narrow base, a wider crest and a lingual undercut on the lingual
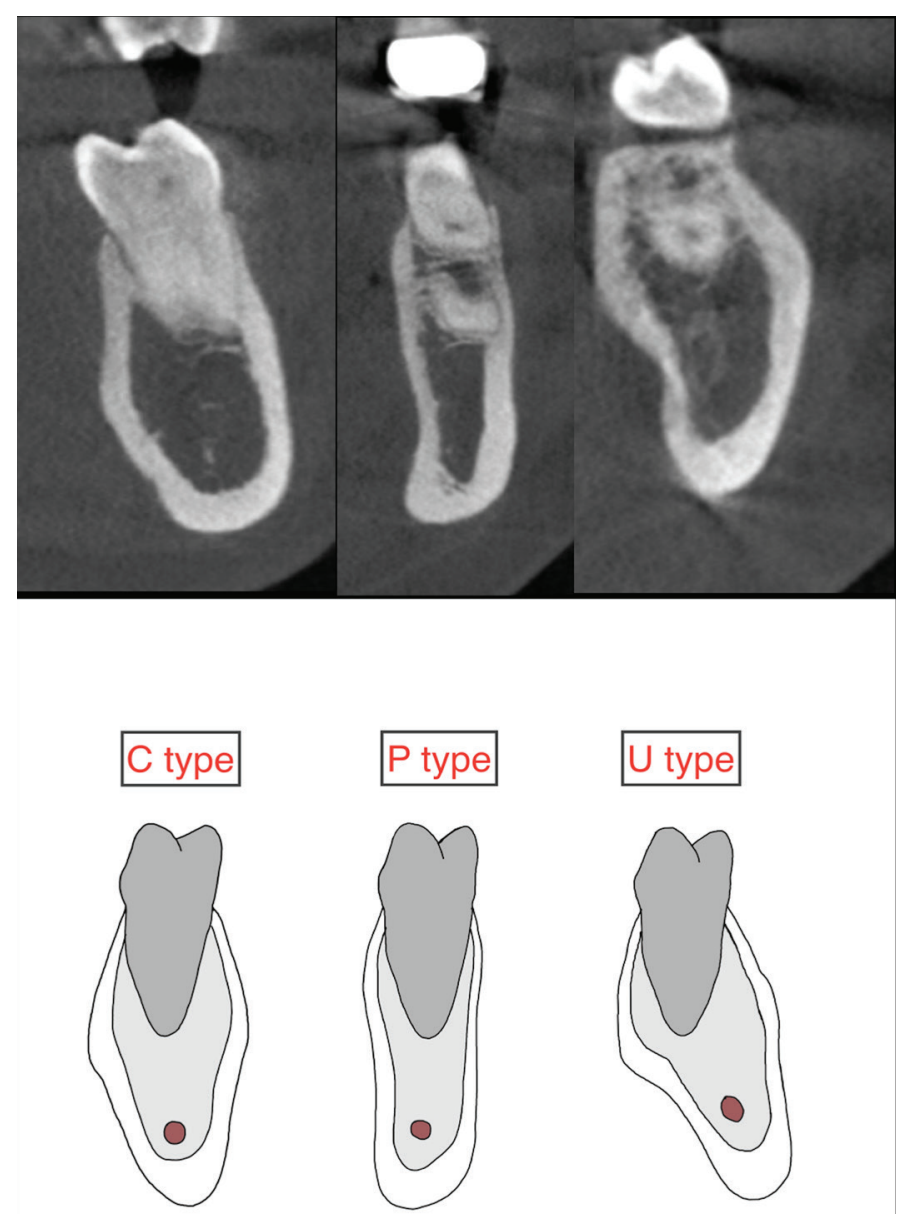

Figure 2. Three types of mandibular cross-sectional ridge morphology (CST) were determined. 
plate. The $C$ type was a ridge with no obvious lingual undercut. The $P$ type was defined as parallel ridge boundaries of the mandible buccolingually (Figure 2).

In the literature, the presence of $4-\mathrm{mm}$ native bones is considered the minimum requirement to provide primary stability for implant survival $(14,15)$. In the present study, the amount of bone apical to the socket that was deemed necessary for IIP was $6 \mathrm{~mm}$ to allow $4 \mathrm{~mm}$ for primary stability and $2 \mathrm{~mm}$ as a safety zone $(11,13,16)$. To determine whether there was a high risk of nerve injury, a measurement was made on the coronal sections of the mandibular first and second molars. Using computer software, a vertical line was traced from the level of the apices of the mesial root of the mandibular first and second molars to the superior border of the IAC. This was designated as the root to alveolar canal (RAC) distance ( $\mathrm{mm}$ ) (Figure 3).

A 4-mm diameter single tapered implant was selected from the software database. Without considering the lingual plate and IAC, all implants were placed according to the following criteria. Mesiodistally, the implants were placed along an imaginary line connecting the central grooves of the teeth. Buccolingually, the centre of the implant was placed along a line passing through the middle of the marginal ridge of the buccal and lingual aspects of each tooth. The mesiodistal and buccolingual angulation of the implant depended on the axis of the implant parallel to the long axis of the existing tooth. The functional cusps of the opposing

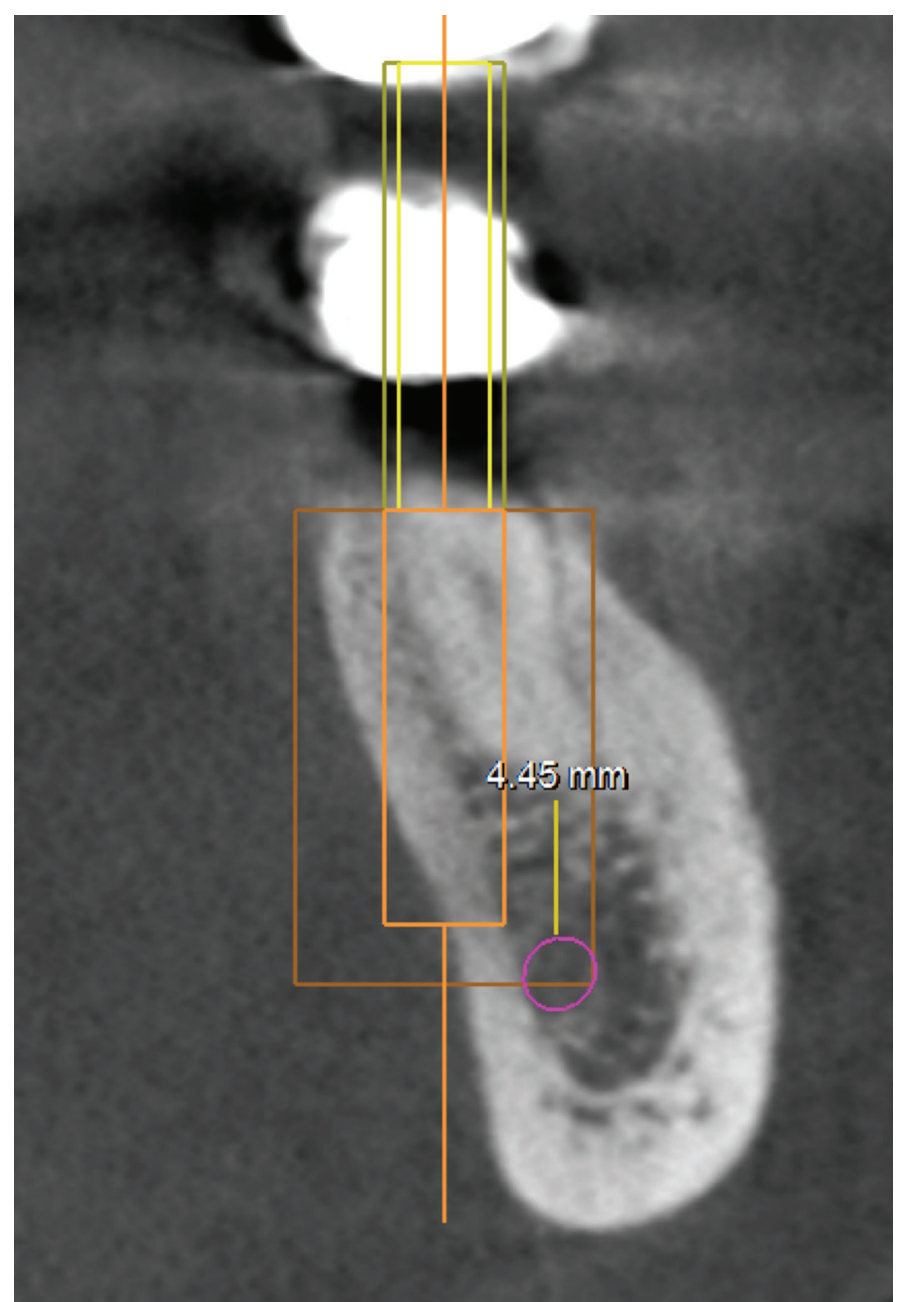

Figure 3. The simulation was categorized as LPP if the virtual implant extruded the outline of cortical bone in the cross-sectional images. teeth were positioned at the centre of the implant. The software was used to verify the position of the virtual implant in different planes. A high risk of MCP was defined as a virtual implant placed within $4 \mathrm{~mm}$ of the native bone and in contact with the IAC. A high risk of LPP was defined as an implant that exceeded the outline of the lingual plate (Figure 3). All measurements were made by a dental surgeon (S.D) with $14 \mathrm{y}$ of experience and a PhD degree in oral surgery.

\section{Statistical analysis}

NCSS software (Number Cruncher Statistical System, 2007, UT, USA) was used for statistical evaluation. The normality of the data was assessed using Kolmogorov-Smirnov and Shapiro-Wilk tests. If the variables were distributed normally, a binary group comparison was undertaken with an independent $t$-test. For variables that were not distributed normally, a between-group comparison was conducted using the Kruskal-Wallis test. A Mann-Whitney $U$ test was applied for the binary group comparison, qualitative data comparisons were conducted using a chi-squared test, and Spearman's rank correlation coefficient test was performed for identification of relationships between variables $(r<0.2$ : no correlation, 0.2-0.4: a weak correlation, 0.4-0.6: a moderate correlation, and 0.6-0.8: a strong correlation). The level of significance was considered as $P<0.05$.

\section{Results}

In total, CBCT images obtained from 135 patients (males: $n=62,46.5 \%$; females, $n=73,53.5 \%$ ) aged $18-84$ y were selected for inclusion in the study. The mandibular first molars were observed in 136 (46\%) patients, and the mandibular second molars were studied in 156 (54\%) patients. In the study group, the $U$ type was the most common (50.65), followed by the P (36.9\%) and C types (12.3\%) (Figure 4).

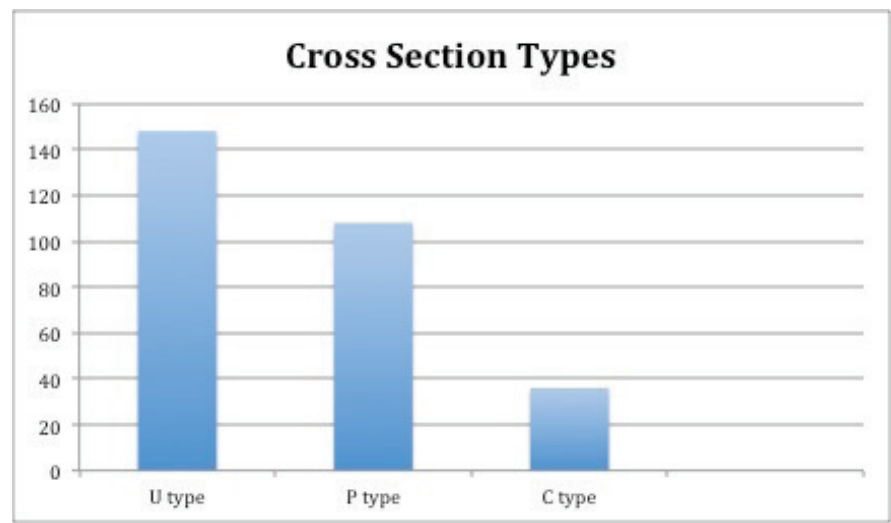

Figure 4. Distribution of cross section types.

\section{Risk of LPP}

The positive risk group of LPP was significantly older than negative risk group ( $p=0.039,<0.05)$. There was a significant relationship between the risk of LPP and cross-section type $\mathrm{U}(p=0.0001,<0.05)$. There was no statistically meaningful relationship between the risk of LPP and sex. The risk of LPP was significantly higher in second molars than first 
molars ( $p=0.0001,<0.05)$. A high risk of LPP was observed in $24.6 \%$ of the study group (1.4\% of first molars and $23.2 \%$ of second molars) (Table 1 ).

\section{Risk of MCP}

In the study group, $73.9 \%$ of the patients had a risk of MCP. Similar to the risk of LPP, the MCP risk increased with age ( $p$ $=0.0001,<0.05)$. There was no statistically meaningful relationship between the risk of MCP and sex. However, there was a significant relationship between the risk of MCP and cross-section type $U(p=0.0001,<0.05)$. Although MCP in- creased in second molars, there was no statistically significant relationship between MCP and tooth type (Table 2).

\section{Cross-section type}

There was no statistically meaningful relationship between cross-section type and sex.

\section{RAC measurement}

The mean RAC value of males was significantly higher than that of females (5.02 $\mathrm{mm}$ versus $3.49 \mathrm{~mm}$ ). The RAC mea-

Table 1. Frequency distribution of lingual plate perforation of each tooth type, sex and cross section type (*independent $t$-test, +Chi square test)

\begin{tabular}{|c|c|c|c|c|}
\hline & & LPP yes & LPP no & p value \\
\hline Age (mean \pm SD) & & $47,95 \pm 13,55$ & $42,39 \pm 14,76$ & $0.039^{*}$ \\
\hline \multirow{2}{*}{ Sex } & Male & 12 & 51 & \multirow{2}{*}{$0.287+$} \\
\hline & Female & 19 & 53 & \\
\hline \multirow{2}{*}{ Tooth } & M1 & 4 & 112 & \multirow{2}{*}{$0.0001+$} \\
\hline & M2 & 68 & 108 & \\
\hline \multirow{3}{*}{ CST } & U & 68 & 80 & \multirow{3}{*}{$0.0001+$} \\
\hline & $\mathrm{P}$ & 0 & 108 & \\
\hline & $\mathrm{C}$ & 4 & 32 & \\
\hline
\end{tabular}

M1: First Molar, M2: Second Molar, SD: Standart deviation, LPP: Lingual plate perforation, CST: Cross section type

Table 2. Frequency distribution of nerve injury risk of each tooth type, sex and cross section type $\left({ }^{*}\right.$ independent $t$-test, + Chi square test)

\begin{tabular}{|c|c|c|c|c|}
\hline & & MCP yes & MCP no & $p$ value \\
\hline Age (mean \pm SD) & & $55,21 \pm 14,21$ & $43,54 \pm 12,67$ & $0,0001 *$ \\
\hline \multirow{2}{*}{ Sex } & Male & 43 & 19 & \multirow{2}{*}{$0,104+$} \\
\hline & Female & 59 & 14 & \\
\hline \multirow{2}{*}{ Tooth } & M1 & 88 & 28 & \multirow{2}{*}{$0,673+$} \\
\hline & M2 & 128 & 48 & \\
\hline \multirow{3}{*}{ CST } & $U$ & 132 & 16 & \multirow{3}{*}{$0.0001+$} \\
\hline & $\mathrm{P}$ & 58 & 50 & \\
\hline & $\mathrm{C}$ & 26 & 10 & \\
\hline
\end{tabular}

M1: First Molar, M2: Second Molar, SD: Standart deviation, CST: Cross section type, MCP: Mandibular canal perforation

Table 3. Frequency distribution of three types of cross-sectional morphology, sex and tooth types and RAC values (tMann Whitney U testi $\neq$ Æruskal Wallis testi)

\begin{tabular}{|c|c|c|c|c|}
\hline & Number & & $R A C, m m$, mean $\pm S D$ & p value \\
\hline \multirow{2}{*}{ Sex } & Male & 62 & $5,02 \pm 2,63$ & \multirow{2}{*}{$-0,001+$} \\
\hline & Female & 73 & $3,49 \pm 2,52$ & \\
\hline \multirow{2}{*}{ Tooth } & M1 & 136 & $4,30 \pm 2,74$ & \multirow{2}{*}{$-0,665+$} \\
\hline & M2 & 156 & $4,13 \pm 2,64$ & \\
\hline \multirow{3}{*}{ CST } & U & 148 & $3,57 \pm 2,30$ & \multirow{3}{*}{$0,0001 \neq$} \\
\hline & $P$ & 108 & $5,33 \pm 2,72$ & \\
\hline & $\mathrm{C}$ & 36 & $3,42 \pm 2,98$ & \\
\hline
\end{tabular}


surement decreased with age $(r=0.414))$. The RAC values for cross-section type $P$ were significantly higher than those of the other types. There was no statistically meaningful difference between the RAC values of cross-section types $U$ and C (Table 3).

\section{Discussion}

Dental implant therapy commences with extraction, followed by healing of soft and hard tissue, osteotomy and implant placement. Maximum bone implant contact was thought to be achieved by adopting the aforementioned procedure $(17,18)$. The popularity of IIP is due to the need for only one surgical procedure and a reduced overall treatment time $(19,20)$. The implant survival rate is an added benefit of IPP, with an immediate implant survival rate of $95 \%$ in the posterior mandible reported in the literature $(21,22)$.

Initial stability is important for the survival of implants immediately after placement. The extraction socket must be examined to investigate whether it is suitable for IIP. Observations during surgery will determine whether the implant can be placed during or after surgery (i.e. after hard and soft tissue healing). Micro-movements between the implant and bone should be evaluated to assess the likelihood of successful healing. In the present study, the amount of bone apical to the socket that was deemed necessary for IIP was $6 \mathrm{~mm}$. This allowed $4 \mathrm{~mm}$ for apical bone support and a 2-mm safety zone to avoid nerve damage $(11,13,16)$. Although some studies have suggested implant placement in the inter-septal bone of multi-rooted mandibular molars during an IIP protocol, the quality of cancellous bone means it is not ideal for implant placement. Moreover, the bone between the roots will be lost while drilling (23). To avoid such problems, we ensured that our measurements were made at the mesial root apex. The diameter was fixed at $4 \mathrm{~mm}$, representing the minimum implant diameter required to support an occlusal load in the posterior mandible while minimising the risk of $\operatorname{LPP}(24,25)$.

Lin et al. (26) reported in a virtual implant placement study that $51.7 \%$ of 1,008 teeth had a risk of MCP in IPP procedures. They used an RAC value of $6 \mathrm{~mm}$ as the safety margin. In the present study, the mean RAC value was $5.02 \mathrm{~mm}$ for males and $3.49 \mathrm{~mm}$ for females. Only $26 \%$ of the subjects had an RAC distance of $>6 \mathrm{~mm}$.

Previous studies examined the occurrence of LPP and sublingual or submandibular hematomas, excessive bleeding and infection $(9,10,11)$. Froum et al. (15) reported that $9 \%$ of first molars and $31 \%$ of second molars had a high risk of LPP in cases of IMPs $4 \mathrm{~mm}$ in diameter. In the present study, $1.4 \%$ of first molars and $23.2 \%$ of second molars showed a high risk of LPP when placing an immediate implant $4 \mathrm{~mm}$ in diameter. In cases of implants with larger diameters, the probability of LPP would increase.

In the present study, the $U$ type was the most common type $(50.6 \%)$ of mandibular cross-sectional morphology in the study group. The $\mathrm{P}$ type was the second most common (36.9\%), followed by the $C$ type (12.3\%). The findings of the present study are in accordance with those of Chan et al. (14), who reported that the $U$ type (lingual concavity) accounted for $66 \%$ of cross-section types in their study population. Yu et al. (27) reported similar results in a Taiwanese study population (U type: 50\%). However, Watanebe et al.
(28) reported that the $C$ type was the most common in their study of a Japanese population. The difference might be the result of the study design, analysed areas and ethnicity of the sample (14).

A number of systematic reviews and consensus documents have reported that the survival rates of short posterior mandible implants are comparable to those of conventional posterior mandible implants $(29,30)$. Thus, short implants may be an alternative to conventional implants in complicated cases.

Although this study was designed under the guidance of current scientific data, it has some limitations, , such as differences in the risk of LPP and MCP in implants with different diameters, different placement depths and various implant designs. Further studies that include both implants with different diameters and different types of implants are needed. As this study comprised a virtual simulation, translation of the data to the clinic may not be possible.

\section{Conclusion}

The results of the present study suggest that the IIP procedure in the mandibular molar area carries a high risk of LPP (1.4\% for first molars and $23.2 \%$ for second molars) in cases of IMP where the diameter of the implant is $4 \mathrm{~mm}$. These complications may lead to debilitating and even life-threatening situations for the patient. Based on the high level of risk, a delayed implant protocol should be considered.

Türkçe Öz: Mandibular molar bölgede protezin yönlendirdiği immediate implant yerleştirilmesi; anatomik çalışma. Amaç: Immediate implant yerleştirmenin(IIP) etkinliğini ve güvenliğini incelemek için, volumetrik bilgisayarlı tomografi görüntüleri kullanılarak posterior mandibula anatomisi ile ilişkili lingual plak perforasyonu (LLP) ve mandibular kanal perforasyonu (MCP) riskini değerlendirdik. Gereç ve yöntem: 135 hastanın molar soketlerinin morfolojik incelemesi ve bunun inferior alveolar sinir kanalı ile ilişkisi araştırıldı. LLP ve MCP riski evet veya hayır olarak kaydedildi. Altçene çapraz kesit morfolojisi, Chan et al ölçütlerini kullanarak üç tipten biri ( $u p c)$ olarak tanımlandı. Bulgular: LLP riski ikinci molar dişler $(p=0.0001)$ için önemli derece daha fazlaydı, ve bu risk yaş $(p=0.039)$ ile birlikte artmaktaydı. $L L P$ riski ile U tipi kesit $(p=0.0001)$ arasında güçlü bir bağlantı vardı. Erkeklerdeki alveolar kanal (RAC) mesafesi $(\mathrm{mm})$ ortalamasının kökü kadınlarınkine göre önemli derece daha yüksekti. Erkekler için ortalama RAC değeri $5.02 \mathrm{~mm}$ ve kadınlarınki de $3.49 \mathrm{~mm}$ idi. MCP riski ve cinsiyet arasında istatistiki olarak önemli bir bağlantı yoktu. MCP riski ile U tipi kesit $(p=0.0001)$ arasında önemli bir bağlantı vardı. $M C P$ riski ikinci molarlarda daha yüksek olmasına rağmen $M C P$ ve molarlar arasında istatistiki olarak anlamlı bir bağlantı yoktu. Sonuç: Sonuç, mandibular molar bölgede IIP'nin yüksek bir MCP ve LPP riski taşıdığını göstermektedir. Yüksek risk seviyesi düşünülerek, gecikmiş bir implant yerleştirme protokolü göz önünde bulundurulmalıdır. Anahtar kelimeler: CBCT; immediate implant; mandibular kanal; lingual plak perforasyonu; çene

Ethics Committee Approval: The study protocol was approved by the institutional review board of the Istanbul University Faculty of Dentistry (2016-83).

Informed Consent: The informed consents were provided by the participants.

Peer-review: Externally peer-reviewed.

Author contributions: SD designed the study, generated and gathered the data, wrote and approved the final version of the study. 
Conflict of Interest: The author had no conflict of interest to declare.

Financial Disclosure: The author declared that he received no financial support.

\section{References}

1. Ak G, Sepet E, Pinar A, Aren G, Turan N. Reasons for early loss of primary molars. Oral Health Prev Dent 2005;3:113-7.

2. Alexander $S A$, Askari $M$, Lewis $P$. The premature loss of primary first molars: space loss to molar occlusal relationships and facial patterns. Angle Orthod 2015;85:218-23. [CrossRef]

3. Schulte W, Kleineikenscheidt H, Lindner K \& Schareyka R. The Tubingen immediate implant in clinical studies. Deutsche Zahnarztliche Zeitschrift 1978;33:348-59.

4. Esposito M, Grusovin MG, Polyzos IP, Felice P, Worthington HV. Interventions for replacing missing teeth: dental implants in fresh extraction sockets (immediate, immediate-delayed and delayed implants). Australian Dental Journal 2011;56:100-2. [CrossRef]

5. Chiapasco $M$, Casentini P. Horizontal bone-augmentation procedures in implant dentistry: prosthetically guided regeneration. Periodontol 2000 2018;77(1):213-40. [CrossRef]

6. Aksoy U, Orhan K. Risk Factor in Endodontic Treatment: Topographic Evaluation of Mandibular Posterior Teeth and Lingual Cortical Plate Using Cone Beam Computed Tomography (CT). Med Sci Monit 2018;24:7508-16. [CrossRef]

7. Ozturk CN, Ozturk C, Bozkurt M, Uygur HS, Papay FA, Zins JE. Dentition, bone loss, and the aging of the mandible. Aesthet Surg J 2013;1;33(7):967-74. [CrossRef]

8. Vallabh R, Zhang J, Fernandez J, Dimitroulis G, Ackland DC. The morphology of the human mandible: A computational modelling study. Biomech Model Mechanobiol. 2019 Mar 2. (Epub ahead of print) [CrossRef]

9. Misch CE, Resnik R. Mandibular nerveneurosensory impairment after dental implant surgery: management and protocol. Implant Dentistry 2010;19:378-86. [CrossRef]

10. Renton $\mathrm{T}$, Janjua $\mathrm{H}$, Gallagher JE, Dalgleish M, Yilmaz Z. UK dentists' experience of iatrogenic trigeminal nerve injuries in relation to routine dental procedures: why, when and how often? Br Dent J 2013;214(12):633-42. [CrossRef]

11. Chan HL, Benavides E, Yeh CY, Fu JH, Rudek IE, Wang HL. Risk assessment of lingual plate perforation in posterior mandibular region: a virtual implant placement study using cone-beam computed tomography. Journal of Periodontology 2011;82:12935. [CrossRef]

12. Gonz.lez-Garc.a R, Monje F. The reliability of cone-beam computed tomography to assess bone density at dental implant recipient sites: a histomorphometric analysis by micro-CT. Clin Oral Implants Res 2013;24:871-9. [CrossRef]

13. Salimov F, Tatli U, Kürkçü $M$, Akoğlan $M$, Oztun. H, Kurtoğlu C. Evaluation of relationship between preoperative bone density values derived from cone beam computed tomography and implant stability parameters: a clinical study. Clin Oral Implants Res 2014;25:1016-21. [CrossRef]

14. Chan HL, Brooks SL, Fu JH, Yeh CY, Rudek I, Wang HL. Crosssectional analysis of the mandibular lingual concavity using cone beam computed tomography. Clinical Oral Implants Research 2011;22:201-6. [CrossRef]
15. Froum S, Casanova L, Byrne S, Cho SC. Risk assessment before extraction for immediate implant placement in the posterior mandible: a computerized tomographic scan study. Journal of Periodontology 2011;82:395-402. [CrossRef]

16. Misch CE. Root form surgery in the edentulous mandible: Stage I implant insertion. In: Misch CE, ed. Implant Dentistry, 2nd ed. St. Louis: The CV Mosby Company; 1999;347-37:

17. Brånemark $\mathrm{Pl}$, Hansson $\mathrm{BO}$, Adell $\mathrm{R}$, Breine $\mathrm{U}$, Lindström J, Hallén $\mathrm{O}$, Ohman A. Osseointegrated implants in the treatment of the edentulous jaw. Experience from a 10-year period. Scand J Plast Reconstr Surg Suppl 1977;16:1-132.

18. Podaropoulos L. Increasing the Stability of Dental Implants: the Concept of Osseodensification. Balkan Journal of Dental Medicine 2017;21:133-40. [CrossRef]

19. Hong DGK, Oh JH. Recent advances in dental implants. Maxillofac Plast Reconstr Surg 2017;39(1):33. [CrossRef]

20. Chen ST, Darby IB, Reynolds EC, Clement JG. Immediate implant placement postextraction without flap elevation. J Periodontol 2009;80:163-72. [CrossRef]

21. Rosenquist B, Grenthe B. Immediate placement of implants into extraction sockets: Implant survival. Int J Oral Maxillofac Implants 1996;11:205-9. [CrossRef]

22. Grunder U, Polizzi G, Goene' R, et al. A 3-year prospective multicenter follow-up report on the immediate and delayedimmediate placement of implants. Int J Oral Maxillofac Implants 1999;14:210-6.

23. Wagenberg B, Froum SJ. A retrospective study of 1925 consecutively placed immediate implants from 1988 to 2004. Int J Oral Maxillofac Implants 2006;21:71-80.

24. Brunski JB. Biomechanics of oral implants: Future research directions. J Dent Educ 1988;52:775-87.

25. Branemark PI, Zarb G, Albrektsson T. Tissue Integrated Prostheses: Osseointegration in Clinical Dentistry. Chicago: Quintessence; 1985:11-76.

26. Ming-Hung Lin, Lian-Ping Maub, David L. Cochran, Yi-Shing Shieh, Po-Hsien Huang, Ren-Yeong Huang. Risk assessment of inferior alveolar nerve injury for immediate implant placement in the posterior mandible: A virtual implant placement study. J Dent 2014;42(3):263-70. [CrossRef]

27. Yu DC, Friedland BD, Karimbux NY, Guze KA. Supramandibular canal portion superior to the fossa of the submaxillary gland: a tomographic evaluation of the cross-sectional dimension in the molar region. Clinical Implant Dentistry and Related Research 2012;15:750-8. [CrossRef]

28. Watanabe H, Mohammad Abdul M, Kurabayashi T, Aoki H. Mandible size and morphology determined with CT on a premise of dental implant operation. Surg Radiol Anat 2010;32(4):343-9. [CrossRef]

29. Atieh MA, Zadeh H, Stanford CM, Cooper LF. Survival of short dental implants for treatment of posterior partial edentulism: A systematic review. The International Journal of Oral and Maxillofacial Implants 2012;27:1323-31.

30. Fan T, Li Y, Deng WW, Wu T, Zhang W. Short im-plants (5 to $8 \mathrm{~mm}$ ) versus longer implants $(>8 \mathrm{~mm}$ ) with sinus lift-ing in atrophic posterior maxilla: A meta-analysis of RCTs. Clinical Implant Dentistry and Related Research 2017;19:207-15. [CrossRef] 